\title{
Chitosan nanoparticles for the intracellular delivery of triphosphate nucleotide analogues
}

\author{
Giovanna Giacalone*, Elias Fattal, Hervé Hillaireau \\ From Abstracts from International Symposium HIV and Emerging Infectious Diseases 2014 \\ Marseille, France. 21-23 May 2013
}

\begin{abstract}
Aim
Nucleotide analogues such as Azidothymidine-triphosphate (AZT-TP), the active form of Zidovudine, display an important pharmacological activity for the treatment of HIV. The administration of these nucleotide analogues would bypass the intracellular phosphorylation which can be a metabolic bottleneck. This possibility is however limited by their instability in physiological conditions, and furthermore their hydrophilicity restricts their access to the target cells. Several nanocarriers have been proposed so far for the encapsulation of these molecules, but their applications are limited due to the low drug loading achieved. Our strategy proposes the use of chitosan, a biocompatible and hydrophilic polysaccharide which is known to form nanoparticles through complexation with TPP; in contrast with previous methods, in our case the drug itself will be the driving force for the formation of nanoparticles [1].
\end{abstract}

\section{Material and methods}

Different molar ratios between chitosan and AZT-TP (or ATP, used here as a model drug) have been tested in order to study the formation of nanoparticles; some selected ratios have been then evaluated for their size, surface properties, drug encapsulation and loading. In vitro cell uptake experiments were performed on a cell line of macrophages, using the free molecule as a negative control. The intracellular distribution of the delivered molecules was further investigated using confocal laser microscopy.

\section{Results}

Colloidal suspensions have been obtained from chitosan and AZT-TP; nanoparticles present a minimal size about $200 \mathrm{~nm}$ with a zeta potential above $+20 \mathrm{mV}$. An encapsulation efficiency of $70 \%$ can be reached, allowing loading rates as high as $44 \%$. A cell viability of $80 \%$ has

Galien Paris-Sud Institute, UMR 8612, Châtenay-Malabry, France been found for particle concentrations up to $0.6 \mathrm{mg} / \mathrm{mL}$. The cellular uptake is at least 2-fold higher when molecules are delivered as nanoparticles, compared to the free molecules.

\section{Conclusions}

An original method is proposed to design nanoparticles, which allows high loading rates; this lowers the amounts of excipients needed, thus limiting the toxicity concerns. These nanosystems allow an efficient in vitro intracellular delivery of nucleotide analogues. Further in vivo studies will investigate the potential of these nanocarriers.

\section{Published: 23 May 2014}

\section{Reference}

1. Giacalone G, Bochot A, Fattal E, Hillaireau H: Drug-Induced Nanocarrier Assembly as a Strategy for the Cellular Delivery of Nucleotides and Nucleotide Analogues Biomacromolecules. Biomacromolecules 2013, 14(3):737-742.

doi:10.1186/1471-2334-14-S2-P75

Cite this article as: Giacalone et al.: Chitosan nanoparticles for the intracellular delivery of triphosphate nucleotide analogues. BMC Infectious Diseases 2014 14(Suppl 2):P75.

Submit your next manuscript to BioMed Central and take full advantage of:

- Convenient online submission

- Thorough peer review

- No space constraints or color figure charges

- Immediate publication on acceptance

- Inclusion in PubMed, CAS, Scopus and Google Scholar

- Research which is freely available for redistribution 